\title{
EFISIENSI TEKNIS BANK DI INDONESIA: KELOMPOK BUKU I-IV
}

\author{
Romauli Nainggolan
}

Jurusan Manajemen, Universitas Ciputra, Surabaya

Email: romauli.nainggolan@ciputra.ac.id

\begin{abstract}
ABSTRAK
Efisiensi Bank merupakan salah satu ukuran kinerja bank. Bank harus berusaha mengelola input dan output bank secara optimal. Efisiensi bank yang optimal dapat dilihat dari tingkat efisiensi teknis bank. Penelitian ini bertujuan mengukur efisiensi teknis bank di Indonesia. Penelitian dilakukan pada 38 bank berdasarkan kelompok bank BUKU I-IV periode 2012 - 2018 dengan metode DEAP. Variabel input dan output bank menggunakan pendekatan Intermediasi bank. Variabel input bank yaitu price of fund, price of labor and price of capital. Sedangkan output bank yaitu loans. Pengukuran efisiensi teknis menggunakan DEAP sebagai pengukur efisiensi secara modern. Hasil penelitian metode DEAP dengan model Constant Return to Scale (CRS) menunjukkan bahwa Bank BNI dan bank BCA paling efisiensi secara teknis dibanding bank lainnya dengan efisiensi teknis $100 \%$. Bank kelompok BUKU IV secara umum telah mencapai efisiensi teknis sedangkan Bank kelompok BUKU I-III belum mencapai efisiensi teknis. Pada periode 2018, dalam mencapai efisiensi teknis maka kelompok bank BUKU I-III harus melakukan kebijakan dengan cara mengendurkan atau mengurangi biaya dua input. Kedua input variabel yaitu input price of fund dan price of capital karena kedua input tersebut yang membuat bank belum mencapai efisiensi teknis.
\end{abstract}

Kata Kunci: DEAP, efisiensi teknis, BUKU I-IV, bank

\begin{abstract}
Efficiency of Bank is a measure of bank performance. The banking sector must try to regulate bank inputs and outputs optimally. Optimal efficiency can be seen from the bank's technical efficiency score.. This study aims to measure the technical efficiency of banks in Indonesia. The study was conducted on 38 banks based on the BUKU I$I V$, period 2012 - 2018 with the DEAP method. Bank input and output variables use the bank intermediation approach. Bank input variables are price of funds, price of labor and price of capital. Bank output is loans. Measurement of technical efficiency using DEAP as a measure of modern efficiency. The DEAP method research results with the Constant Return to Scale (CRS) model show that BNI Bank and BCA bank are the most technically efficient compared to other banks with 100\% technical efficiency. BUKU IV group banks in general have achieved technical efficiency while BUKU I-III group banks have not technical efficiency. In achieving technical efficiency, the BUKU I-III bank group must carry out policies by relaxing or reducing the costs of two inputs. The two variable inputs are input price of funds and price of capital because these two inputs have made the bank not yet reached technical efficiency.
\end{abstract}

Keywords: DEAP, technical efficiency,BUKU I-IV, bank.

\section{PENDAHULUAN}

\section{Latar Belakang}

Bank sehat memiliki kinerja yang baik. Kinerja bank yang baik terukur dengan efisiensi bank. Sehingga Bank Indonesia berperan penting dalam mendukung industri perbankan meningkatkan efisiensi bank. Upaya pertama untuk mencapai hal tersebut, Bank Indonesia berkoordinasi dan bekerjasama dengan Otoritas Jasa Keuangan (OJK) serta Lembaga Penjamin Sosial (LPS) (Bank Indonesia, 2018). Sejak tahun 2011, Bank Indonesia mewajibkan bank umum yang memiliki aset di atas Rp 10 triliun untuk mempublikasikan suku bunga dasar kredit sebagai upaya untuk implementasi program efisiensi perbankan nasional. Di sisi lain, peraturan OJK Nomor 6 tahun 2016 tentang kegiatan usaha dan Jaringan kantor membagi bank berdasarkan modal inti bank. Karena bank dengan jumlah modal inti makin besar memiliki efisiensi lebih tinggi dibandingkan bank umum dengan modal kecil dan menengah (Lee, 2017). 
Tercatat sejak tahun 2013 sampai 2018, jumlah bank umum berkurang dari 120 bank menjadi 115 bank. Bank dengan kinerja keuangan yang baik dapat bertahan dalam persaingan industri perbankan. Kinerja efisiensi bank dapat dipengaruhi oleh faktor eksternal dan internal bank. Faktor internal bank adalah variabel yang berasal dari akun-akun bank seperti laporan laba rugi, laporan keuangan, dan laporan kinerja bank. Sedangkan faktor eksternal bank adalah variabel yang tidak berhubungan dengan manajemen bank namun dapat merefleksikan kondisi ekonomi maupun regulasi yang dapat mempengaruhi kinerja lembaga keuangan (I.Papanikolaou, 2009).

Upaya kedua, munculnya peraturan OJK Nomor 6/POJK.03/2016 tentang Kegiatan Usaha dan Jaringan Kantor membagi bank berdasarkan modal inti bank. Bank dengan modal inti di atas Rp 30 triliun di kategorikan Bank Umum Kegiatan Usaha 4 (BUKU 4). Bank dengan modal inti di antara Rp 5 - 30 triliun di kategorikan Bank Umum Kegiatan Usaha 3 (BUKU 3). Bank dengan modal inti di antara Rp 1 - 5 triliun di kategorikan Bank Umum Kegiatan Usaha 2 (BUKU 2). Bank dengan modal inti di bawah Rp 1 triliun di kategorikan Bank Umum Kegiatan Usaha 1 (BUKU 1). Pembagian bank berdasarkan modal inti bertujuan mendorong bank meningkatkan efisiensinya.

Beberapa penelitian terkait efisiensi bank di kaji pada banyak negara. Kajian pada sektor perbankan dibagi berdasarkan kategori bank. Kategori yang dimaksud adalah kategori kepemilikan bank, kategori kegiatan bank dan kategori wilayah bank. Penelitian oleh Sari \& Saraswati (2017) meninjau data perbankan Indonesia periode 2012-2014 kategori kepemilikan bank. Hasil tinjauan mengungkapkan bahwa kelompok bank dengan skor efisiensi paling tinggi adalah kategori kelompok bank asing, kemudian disusul oleh bank umum milik negara atau pemerintah daerah, kelompok bank swasta nasional non devisa, bank swasta nasional devisa, dan bank campuran.

Kategori kepemilikan bank dikaji oleh Lee (2017) terkait efisiensi bank di Negara Korea pada dua periode yaitu sebelum dan sesudah krisis. Hasil kajian menunjukkan skor relatif efisien pada 17 bank di Korea pada kategori bank lokal dan bank nasional. Penelitian oleh Stewart et al. (2016) periodel 1999- 2009 mengkaji efisiensi bank berdasarkan kategori kelompok bank besar, menengah dan bank kecil di Vietnam. Penghitungan efisiensi menggunakan metode DEA menunjukkan bahwa kategori kelompok bank besar dan bank sangat besar lebih efisien dibandingkan bank kecil dan menengah. Serta kategori bank milik swasta lebih efisien dibandingkan bank milik pemerintah.

Penelitian oleh Grmanová \& Ivanová (2018) menghitung efisiensi 13 bank di Slovakia menggunakan metode DEA modern. Hasil penelitian menunjukkan bahwa kategori bank nasional terbesar yang paling efisien diantara bank lainnya. Penelitian oleh Sharma, Sharma, \& Barua (2012) menghitung efisiensi teknis bank di India menggunakan metode DEA. Hasil penelitian menunjukkan bahwa Bank milik pemerintah lebih efisien dibanding bank swasta dan bank asing. Penelitian oleh Balcerzak (2017) melakukan evaluasi efisiensi operasional 80 bank periode 1995-2013 di negara Europa Union. Hasil penelitian ini menunjukkan bahwa adanya perbedaan efisiensi di negara Uni Eropa lama dengan negara Uni Eropa baru. Serta adanya perbedaan efisiensi bank anggota EU zona moneter dengan anggota non zona moneter.

Dari berbagai penelitian terdahulu yang mengkaji efisiensi sektor perbankan berdasarkan kategori bank. Maka penelitian ini akan mengkaji efisiensi bank dengan kategori Bank Umum Kegiatan Usaha (BUKU). Penelitian ini penting dan original karena pertama kali dilakukan dengan kategori bank BUKU I-IV secara bersamaan. Selama ini banyak penelitian nasional 
mengkaji efisiensi bank dengan kategori kepemilikan seperti bank milik pemerintah, bank milik swasta dan bank milik asing.

\section{Rumusan Masalah}

Pentingnya mengukur efisiensi teknis supaya dapat mengungkapkan sejauh mana sektor perbankan mampu mengelola input dan output bank secara optimal. Oleh karena itu, rumusan masalah penelitian ini yaitu bagaimana efisiensi teknis bank kategori BUKU I-IV dan determinan efisiensi bank periode 2012-2018. Pengukuran efisiensi teknis bank menggunakan metode DEA modern (DEAP) pendekatan input oriented model Constant Return to Scale (CRS).

Penelitian ini merupakan penelitian yang pertama kali mengkaji efisiensi teknis semua kelompok bank BUKU I-IV secara bersamaan 38 bank. Penelitian ini berkontribusi memberi pengetahuan dan himbauan bagi bank umum dalam mencapai efisiensi bank secara khusus pengelolaan input dan output bank. Himbauan pertama, pihak perbankan harus berupaya memperbesar dana pihak ketiga yang ditempatkan di Bank Indonesia dan di bank lain dengan cara menarik nasabah lebih banyak untuk berinvestasi. Kedua, pihak perbankan harus mengevaluasi biaya pegawai baik di kantor pusat dan kantor cabang. Karena biaya pegawai yang tinggi tanpa di ikuti capaian perusahaan dengan baik akan menyebabkan inefisiensi bank.

\section{METODE PENELITIAN}

\section{Data Envelopment Analysis (DEA)}

Menghitung efisiensi ada dua pendekatan yaitu pendekatan parametrik dan pendekatan non parametrik. Pada penelitian ini menggunakan pendekatan non-parametrik metode Data Envelopment Analysis (DEA). DEA merupakan pemrograman matematis yang digunakan untuk mengevaluasi efisiensi relatif kumpulan unit unit pembuat keputusan atau Decision Making Unit (DMU) mengelola sumber daya (input) dengan jenis yang sama sehingga menjadi output dengan jenis yang sama pula, dimana hubungan bentuk fungsi dari input ke output tidak perlu diketahui.

Metode DEA pertama kali ditemukan oleh Charnes, Cooper dan Rhodes tahun 1978. Model yang berorientasi pada input berdasarkan asumsi Constant Return to Scale sehingga dikenal dengan model CCR. Model ini mengasumsikan bahwa rasio antara penambahan input dan output adalah sama (constant return to scale). Artinya, jika ada tambahan input sebesar $\mathrm{x}$ kali, maka output akan meningkat sebesar x kali juga. Asumsi lain yang digunakan dalam model ini adalah bahwa setiap perusahaan atau Decision Making Unit (DMU) beroperasi pada skala yang optimal.

Kelebihan DEA dibandingkan dengan alat analisis linear programing ataupun alat analisis efisiensi parsial adalah hasil dari perhitungan DEA dapat memberikan gambaran DMU manakah yang memiliki kinerja lebih efisien dan tingkat efisiensi relatif setiap DMU terhadap DMU lain yang lebih efisien dapat digunakan sebagai referensi yang dapat digunakan untuk mencari penyebab dan solusi atas ketidakefisienan, yang merupakan keuntungan utama dalam aplikasi manajerial (Heidari et al, 2011).

Pada penelitian ini, pengukuran efisiensi teknis bank dengan orientasi input (input oriented) asumsi CRS (Constants Returns to Scale) pada pendekatan DEA. Efisiensi teknis menggambarkan kemampuan perusahaan untuk memilih kombinasi input yang optimal pada harga dan teknologi tertentu. Efisiensi teknis memusatkan perhatian pada kemampuan perusahaan menggunakan input dalam menghasilkan output dengan best practise.

Model tersebut dapat dituliskan sebagai berikut: 


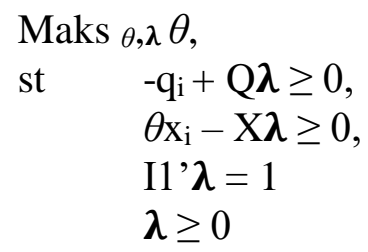

dimana $\theta$ adalah skor efisiensi antara $0-1$. Nilai 1 artinya DMU berada pada frontier atau efisien secara teknik, dan nilai kurang dari 1 artinya DMU tidak bekerja efisien secara teknik. $\boldsymbol{\lambda}$ adalah Ix1 vektor konstanta, $\mathrm{x}_{\mathrm{i}}$ adalah vektor input $i$ dan $\mathrm{q}_{\mathrm{i}}$ adalah vektor output $i$. $\mathrm{X}$ adalah matriks input keseluruhan, $\mathrm{Q}$ adalah keseluruhan matriks output $i$. I1' $\boldsymbol{\lambda}$ merupakan batasan konveksitas yang memastikan bahwa perusahaan yang tidak efisien hanya dibandingkan dengan perusahaan dengan skala yang sama (Coelli, 2005).

\section{Variabel Output dan Input Bank}

Penentuan variabel input dan output bank dalam mengukur efisiensi teknis bank menggunakan pendekatan intermediasi (D.Hadad, 2003). Pendekatan intermediasi melihat bank sebagai perantara keuangan yang mengubah dana yang dihimpun dan menyalurkan dana. Oleh karena itu terdapat tiga variabel input yaitu price of fund, price of capital dan price of labor. Ada satu output bank yaitu loans.

Tabel 1. Definisi Variabel

Sumber : Data internal, 2019

\begin{tabular}{llll}
\hline Simbol & \multicolumn{1}{c}{ Variabel } & \multicolumn{1}{c}{ Defenisi Variabel } & Skala \\
\hline Q & Total loans & \multicolumn{1}{c}{ Output } & Rupiah \\
\hline & & \multicolumn{1}{c}{ Input } & Rp/unit \\
\hline W1 & Price of fund & $\begin{array}{l}\text { Biaya bunga (Interest Expenses)/ dana pihak } \\
\text { ketiga }\end{array}$ & Rp/unit \\
\hline W2 & Price of capital & $\begin{array}{l}\text { Biaya bukan bunga (Non-Interest Income)/ } \\
\text { Aset Tetap }\end{array}$ & Rp/unit \\
\hline W3 & Price labour & Biaya tenaga kerja /Jumlah tenaga kerja & \\
\hline
\end{tabular}

\section{Data}

Sumber data berasal dari laporan keuangan website Bank Indonesia dan Otoritas Jasa Keuangan (OJK). Pemilihan bank berdasarkan kategori modal inti, hal ini dikenal dengan Bank Umum Kegiatan Usaha (BUKU) I - IV. BUKU I merupakan bank dengan modal inti di bawah 1 Triliun Rupiah, tercatat sebanyak 6 bank umum. BUKU II merupakan bank dengan modal inti antara 1 5 Triliun, tercatat sebanyak 14 bank umum. BUKU III merupakan bank dengan modal inti antara 5 - 30 Triliun Rupiah, tercatat sebanyak 13 bank umum. BUKU IV merupakan bank dengan modal inti lebih dari 30 Triliun Rupiah, tercatat sebanyak 5 bank umum. Hal ini dijelaskan pada Tabel 2 di bawah ini.

Tabel 2. Daftar Bank BUKU I - IV

Sumber: OJK, 2018

\begin{tabular}{lll}
\hline Kode bank & \multicolumn{1}{c}{ Nama bank } & \multicolumn{1}{c}{ Kelompok modal inti } \\
\hline B1 & Bank Negara Indonesia & BUKU IV (modal > 30 T) \\
\hline B2 & Bank Mandiri & BUKU IV \\
\hline B3 & Bank Rakyat Indonesia & BUKU IV \\
\hline B4 & Bank MandiriBCA & BUKU IV \\
\hline B5 & Bank CIMB Niaga Tbk & BUKU IV \\
\hline B6 & Bank Ekonomi Raharja & BUKU III (modal 5- 30 T) \\
\hline B7 & Bank Bukopin & BUKU III \\
\hline B8 & Bank Tabungan Negara & BUKU III \\
\hline B9 & Bank Danamon Indonesia & BUKU III \\
\hline B10 & Bank Pembangunan Daerah Jawa Barat & BUKU III \\
\hline B11 & Bank Pembangunan Daerah JATIM & BUKU III \\
\hline
\end{tabular}




\begin{tabular}{lll}
\hline B12 & Bank Maybank Indonesia & BUKU III \\
\hline B13 & Bank Permata & BUKU III \\
\hline B14 & Bank Tabungan Pensiunan Nasional & BUKU III \\
\hline B15 & Bank Mayapada International & BUKU III \\
\hline B16 & Bank Mega & BUKU III \\
\hline B17 & Bank OCBC NISP & BUKU III \\
\hline B18 & Bank Pan Indonesia & BUKU III \\
\hline B19 & Bank BRI Agro & BUKU II (modal 1-5 Triliun) \\
\hline B20 & Bank MNC International & BUKU II \\
\hline B21 & Bank Capital Indonesia & BUKU II \\
\hline B22 & Bank Nusantara Parahyangan & BUKU II \\
\hline B23 & Bank Bumi Arta & BUKU II \\
\hline B24 & Bank Ganesha & BUKU II \\
\hline B25 & Bank Ina Perdana & BUKU II \\
\hline B26 & Bank QNB Indonesia & BUKU II \\
\hline B27 & Bank Maspion Indonesia & BUKU II \\
\hline B28 & Bank Sinar Mas & BUKU II \\
\hline B29 & Bank Victoria & BUKU II \\
\hline B30 & Bank China Construction Bank Indonesia & BUKU II \\
\hline B31 & Bank Nobu & BUKU II \\
\hline B32 & Bank Woori Saudara Indonesia & BUKU II \\
\hline B33 & Bank Artos & BUKU I modal < 1 Triliun \\
\hline B34 & Bank Agris & BUKU I \\
\hline B35 & Bank Of India indonesia & BUKU I \\
\hline B36 & Bank Harda International & BUKU I \\
\hline B37 & Bank Pembangunan Daerah Banten & BUKU I \\
\hline B38 & Bank Yudha & BUKU I \\
\hline
\end{tabular}

Data 38 bank di kutip dari laporan keuangan tahunan periode 2012 - 2018. Data diolah dengan aplikasi DEAP version 2.1 program computer (Coelli, 1996).

\section{HASIL DAN PEMBAHASAN}

\section{Deskripsi Statistik}

Deskripsi statistik menunjukkan minimum, maksimum dan rata rata variabel input dan output bank dari 38 bank umum di Indonesia kategori BUKU I-IV periode waktu 2012-2018.

Tabel 3. Deskripsi Statistik BUKU I

Sumber : OJK, 2019 (dalam Rupiah)

\begin{tabular}{lrrrr}
\hline \multicolumn{1}{c}{ Variabel } & $\mathrm{N}$ & \multicolumn{1}{c}{ Minimum } & \multicolumn{1}{c}{ Maximum } & \multicolumn{1}{c}{ Mean } \\
\hline Total Loans $(Q)$ & 42 & $313,713,000,000$ & $6,788,775,000,000$ & $2,480,306,785,714.29$ \\
\hline Price of fund $(\mathrm{w} 1)$ & 42 & .04632 & .12358 & .0758277 \\
\hline Price of capital $(\mathrm{w} 2)$ & 42 & .22807 & 10.83321 & 4.0822128 \\
\hline Price of labor $(\mathrm{w} 3)$ & 42 & $59,977,661$ & $436,335,260$ & $130,585,050.58$ \\
\hline Valid N & 42 & & & \\
\hline
\end{tabular}

Pada Tabel 3 di atas menunjukkan sebanyak 6 bank kelompok BUKU I selama 7 tahun sehingga $\mathrm{N}=35$. Minimal loans atau kredit yang disalurkan bank BUKU I sebesar 313,7 Miliar dan maksimal 6,7 Triliun. Sangat fantastik pada price of labor dengan biaya minimal 59,9 juta/pegawai dan maksimal 436,3 juta/pegawai. Dengan kata lain rata rata price of labor 130,5 juta/pegawai. 
Tabel 4. Deskripsi Statistik BUKU II

Sumber : OJK, 2019 (dalam Juta Rupiah)

\begin{tabular}{lrrrr}
\hline & $\mathrm{N}$ & \multicolumn{1}{c}{ Minimum } & \multicolumn{1}{c}{ Maximum } & \multicolumn{1}{c}{ Mean } \\
\hline Total Loans (Q) & 98 & $413,521,000,000$ & $22,294,572,000,000$ & $7,214,350,950,642.86$ \\
\hline Price of fund (w1) & 98 & .00321 & .10516 & .0593587 \\
\hline Price of capital (w2) & 98 & .26918 & 37.45187 & 4.5165397 \\
\hline Price of Labor (w3) & 98 & $12,469,896$ & $440,922,964$ & $145,731,724.07$ \\
\hline Valid N & 98 & & &
\end{tabular}

Pada Tabel 4 di atas menunjukkan sebanyak 14 bank kelompok BUKU II selama 7 tahun sehingga $\mathrm{N}=98$. Minimal loans atau kredit yang disalurkan bank BUKU II sebesar 413,5 Miliar dan maksimal 22,2 Triliun. Sangat menarik pada price of labor dengan biaya minimal 12,4 juta/pegawai dan maksimal 440,9 juta/pegawai. Dengan kata lain rata rata price of labor 145,7 juta/pegawai.

Tabel 5. Deskripsi Statistik BUKU III

Sumber : OJK, 2019 (dalam Rupiah)

\begin{tabular}{llrrr}
\hline & $\mathrm{N}$ & \multicolumn{1}{c}{ Minimum } & \multicolumn{1}{c}{ Maximum } & \multicolumn{1}{c}{ Mean } \\
\hline Total Loans (Q) & 91 & $4,777,775,000,000$ & $453,493,000,000,000$ & $83,700,687,219,780.25$ \\
\hline Price of fund (w1) & 91 & .02030 & 18.73958 & .3177607 \\
\hline Price of capital (w2) & 91 & .45921 & 11.04278 & 2.7156513 \\
\hline Price of Labor (w3) & 91 & $72,198,322$ & $977,167,242$ & $232,272,795.38$ \\
\hline Valid N & 91 & & &
\end{tabular}

Pada Tabel 5 di atas menunjukkan sebanyak 13 bank kelompok BUKU III selama 7 tahun sehingga $\mathrm{N}=91$. Minimal loans atau kredit yang disalurkan bank BUKU III sebesar 4,7 Triliun dan maksimal 453,4 Triliun. Pada price of labor minimal 72,1 juta/pegawai dan maksimal 977,1 juta/pegawai. Dengan kata lain rata rata price of labor 232,2 juta/pegawai

Tabel 6. Deskripsi Statistik BUKU IV

Sumber : OJK, 2019 (dalam Rupiah)

\begin{tabular}{lrrrr}
\hline Variabel & N & \multicolumn{1}{c}{ Minimum } & \multicolumn{1}{c}{ Maximum } & \multicolumn{1}{c}{ Mean } \\
\hline Total loans (Q) & 35 & $145,399,129,000,000$ & $843,598,404,000,000$ & $419,535,838,828,571.40$ \\
\hline Price of fund (w1) & 35 & .00058 & .06429 & .0314802 \\
\hline Price of capital (w2) & 35 & .78133 & 6.95025 & 2.1460667 \\
\hline Price of Labor(w3) & 35 & $24,546,639$ & $486,873,261$ & $244,011,991.26$ \\
\hline Valid N & 35 & & & \\
\hline
\end{tabular}

Pada Tabel 6 di atas menunjukkan sebanyak 5 bank kelompok BUKU IV selama 7 tahun sehingga $\mathrm{N}=35$. Minimal loans atau kredit yang disalurkan kelompok bank BUKU IV sebesar 145,3 Triliun dan maksimal 843,5 Triliun. Pada price of labor minimal 24,5 juta/pegawai dan maksimal 486,8 juta/pegawai. Dengan kata lain rata rata price of labor 244 juta/pegawai. Hal ini menarik sekali, dimana price of labor kelompok bank BUKU III dan BUKU IV hampir sama sementara output penyaluran kredit (loans) jauh lebih besar bank BUKU IV.

\section{Hasil Pengukuran Efisiensi Teknis}

Mengukur efisiensi teknis bank dengan orientasi input (input oriented) asumsi CRS (Constants Returns to Scale) dengan tiga input bank dan satu output bank menggunakan aplikasi DEAP 2.1. 
Skor efisiensi teknis antara $0-1$, dimana nilai 1 menunjukkan bahwa bank $100 \%$ bertindak efisien secara teknis. Sedangkan skor mendekati 0 berarti bank semakin tidak efisien secara teknis. Penelitian ini dilakukan pada 38 bank umum yang dikategorikan pada BUKU I - IV. Hasil skor efisiensi teknis bank periode 2012-2018 ditunjukkan pada Tabel 6 di bawah ini.

Tabel 6. Efisiensi Teknis 38 Bank Umum periode 2012-2018

Sumber: Output DEAP Versi 2.1, 2019

\begin{tabular}{|c|c|c|c|c|c|c|c|}
\hline Nama Bank & 2012 & 2013 & 2014 & 2015 & 2016 & 2017 & 2018 \\
\hline BNI1 & 1.000 & 0.982 & 1.000 & 1.000 & 1.000 & 1.000 & 1.000 \\
\hline Mandiri2 & 0.942 & 1.000 & 0.902 & 0.903 & 0.996 & 0.992 & 0.972 \\
\hline BRI3 & 0.925 & 1.000 & 0.937 & 0.933 & 0.932 & 0.941 & 0.946 \\
\hline BCA4 & 1.000 & 1.000 & 0.897 & 1.000 & 1.000 & 1.000 & 1.000 \\
\hline NIAGA5 & 0.952 & 0.976 & 0.891 & 0.876 & 0.881 & 0.887 & 0.891 \\
\hline Ekonomi6 & 0.800 & 0.857 & 0.807 & 0.873 & 0.813 & 0.879 & 0.865 \\
\hline Bukopin7 & 0.870 & 0.955 & 0.880 & 0.889 & 0.871 & 0.885 & 0.978 \\
\hline BTN8 & 0.985 & 0.999 & 0.896 & 0.884 & 0.886 & 0.941 & 0.911 \\
\hline Danamon9 & 0.880 & 0.996 & 0.912 & 0.906 & 0.912 & 0.908 & 0.892 \\
\hline Jabar10 & 0.811 & 0.926 & 0.882 & 0.862 & 0.801 & 0.887 & 0.896 \\
\hline Jatim11 & 0.824 & 0.888 & 0.838 & 0.837 & 0.807 & 1.000 & 0.973 \\
\hline Maybank12 & 0.890 & 0.966 & 0.912 & 0.906 & 0.787 & 0.887 & 0.878 \\
\hline Permata13 & 0.854 & 0.942 & 0.873 & 0.862 & 0.859 & 0.819 & 0.877 \\
\hline BTPN14 & 0.866 & 0.977 & 0.889 & 0.894 & 0.862 & 0.876 & 0.875 \\
\hline Mayapada15 & 1.000 & 1.000 & 0.892 & 0.863 & 0.841 & 0.871 & 0.873 \\
\hline Mega16 & 0.981 & 1.000 & 0.903 & 0.945 & 0.922 & 0.939 & 0.950 \\
\hline OCBC17 & 1.000 & 0.982 & 0.889 & 0.867 & 0.876 & 0.873 & 0.877 \\
\hline Panin 18 & 0.948 & 1.000 & 0.918 & 0.990 & 1.000 & 1.000 & 1.000 \\
\hline Agro19 & 0.805 & 0.877 & 0.831 & 0.821 & 0.827 & 0.835 & 0.855 \\
\hline MNC20 & 0.850 & 0.897 & 0.809 & 0.815 & 0.815 & 0.857 & 0.817 \\
\hline Capital21 & 0.904 & 0.920 & 0.816 & 0.805 & 0.816 & 0.895 & 0.839 \\
\hline NusantaraParah22 & 0.817 & 0.889 & 0.828 & 0.823 & 0.819 & 0.828 & 0.830 \\
\hline Ganesha23 & 0.825 & 0.829 & 0.769 & 0.769 & 0.791 & 0.780 & 0.778 \\
\hline Ina24 & 0.785 & 0.841 & 0.791 & 0.792 & 0.794 & 0.787 & 0.795 \\
\hline QnB25 & 0.889 & 0.894 & 0.831 & 0.834 & 0.826 & 0.842 & 0.804 \\
\hline Maspion26 & 0.880 & 0.899 & 0.836 & 0.902 & 0.882 & 0.961 & 0.926 \\
\hline Bumiarta27 & 0.905 & 0.906 & 0.840 & 1.000 & 1.000 & 1.000 & 1.000 \\
\hline Sinarmas28 & 0.875 & 0.943 & 0.873 & 0.873 & 0.859 & 0.872 & 0.874 \\
\hline Victoria29 & 0.978 & 0.961 & 0.816 & 0.850 & 0.833 & 0.818 & 0.851 \\
\hline China30 & 0.885 & 0.904 & 0.868 & 0.830 & 0.825 & 0.946 & 0.882 \\
\hline NOBU31 & 0.795 & 0.862 & 0.808 & 0.818 & 0.814 & 0.847 & 0.834 \\
\hline Woori32 & 0.902 & 1.000 & 1.000 & 0.853 & 0.848 & 0.860 & 0.880 \\
\hline Artos33 & 0.803 & 0.828 & 0.755 & 0.751 & 0.848 & 0.858 & 0.869 \\
\hline Agris34 & 0.771 & 0.844 & 0.786 & 0.791 & 0.786 & 0.760 & 0.778 \\
\hline India35 & 0.792 & 0.866 & 0.808 & 0.937 & 1.000 & 0.920 & 0.931 \\
\hline Harda36 & 0.816 & 0.840 & 0.788 & 0.786 & 0.782 & 0.777 & 0.787 \\
\hline Pembangunan Banten37 & 0.909 & 0.894 & 0.842 & 0.842 & 0.837 & 0.846 & 0.842 \\
\hline Yudha38 & 0.784 & 0.863 & 0.824 & 0.827 & 0.831 & 0.815 & 0.836 \\
\hline
\end{tabular}

Dari Tabel 6 di atas, pada tahun 2012 menunjukkan ada empat bank dengan efisiensi teknis $100 \%$. Artinya ada empat bank bertindak efisien secara teknis mengelola input dan output bank. Bank BNI dan BCA merupakan kelompok Bank BUKU IV sedangkan Mayapada dan OCBC merupakan kelompok Bank BUKU III. Bank Agris memiliki skor efisiensi teknis paling rendah 
sebesar 77,1\%. Pada tahun 2013 menunjukkan ada enam bank dengan efisiensi teknis 100\%. Artinya enam bank bertindak efisien secara teknis mengelola input dan output bank. Ke-enam bank tersebut adalah Mandiri, BRI, BCA, Maya Pada, Mega, Panin dan Woori. Bank Yudha memiliki skor efisiensi teknis paling rendah sebesar $82,4 \%$.

Pada tahun 2014 menunjukkan hanya satu bank dengan efisiensi teknis 100\%. Artinya hanya bank BNI bertindak efisien secara teknis mengelola input dan output bank, sedangkan bank lain belum efisien. Bank BNI merupakan kelompok Bank BUKU IV dengan modal paling besar. Bank Artos memiliki skor efisiensi teknis paling rendah sebesar 75,5\%. Pada tahun 2015 menunjukkan ada tiga bank dengan efisiensi teknis 100\%. Artinya ke 3 bank bertindak efisien secara teknis mengelola input dan output bank. Ke-tiga bank tersebut adalah BNI, BCA dan Bumiarta. Bank Arthos memiliki skor efisiensi teknis paling rendah sebesar 75,1\%.

Pada tahun 2016 menunjukkan ada lima bank dengan efisiensi teknis 100\%. Artinya ke lima bank bertindak efisien secara teknis mengelola input dan output bank. Ke-lima bank tersebut yaitu BNI, BCA, Panin, Bumiarta dan India. Bank Harda memiliki skor efisiensi teknis paling rendah sebesar 78,2\%. Pada tahun 2017 menunjukkan ada lima bank dengan efisiensi teknis $100 \%$. Artinya ke lima bank bertindak efisien secara teknis mengelola input dan output bank. Ke-lima bank tersebut yaitu BNI, BCA, Jatim, Panin dan Bumiarta. Bank Agris memiliki skor efisiensi teknis paling rendah sebesar $76 \%$.

Pada tahun 2018 menunjukkan ada empat bank dengan efisiensi teknis 100\%. Artinya ke empat bank bertindak efisien secara teknis mengelola input dan output bank. Ke-empat bank tersebut yaitu BNI, BCA, Panin dan Bumiarta. Bank Harda memiliki skor efisiensi teknis paling rendah sebesar 77,8\%. Kajian ini menunjukkan bahwa Bank BNI dan Bank BCA merupakan Bank paling efisien diantara 38 bank lainnya. Karena selama 7 tahun, Bank BNI dan Bank BCA memiliki tingkat efisiensi teknis $100 \%$ secara berturut turut. Bank BNI dan BCA merupakan kelompok bank BUKU IV dengan modal inti paling besar. Hal ini sejalan dengan penelitian yang dilakukan oleh Stewart et al. (2016) bahwa bank sangat besar lebih efisien dibanding bank menengah dan bank kecil.

\section{Pembahasan}

Ditinjau dari hasil deskripsi statistik bahwa kelompok bank BUKU IV memiliki skor efisiensi paling banyak dibandingkan kelompok BUKU lainnya. Selanjutnya dilakukan tinjauan lebih dalam pada kelompok BUKU IV tahun 2018 terkait penggunaan input dan output bank.

Tabel 7. Summary of Input Slack Kelompok Bank BUKU IV 2018 Sumber: Output DEAP Versi 2.1, 2019

\begin{tabular}{cccc}
\hline Bank & Price of fund (w1) & Price of caiptal (w2) & Price of labor (w3) \\
\hline BNI & 0.000 & 0.000 & 0.000 \\
\hline Mandiri & 0.000 & 0.000 & 0.717 \\
\hline BRI & 0.000 & 0.622 & 0.000 \\
\hline BCA & 0.000 & 0.000 & 0.000 \\
\hline NIAGA & 0.006 & 0.177 & 0,000 \\
\hline
\end{tabular}

Pada Tabel 7 di atas menunjukkan bahwa bank BNI dan BCA telah mencapai efisiensi 100\%. Sedangkan 3 bank lain belum mencapai efisiensi. Kebijakan yang perlu diambil oleh beberapa kelompok bank BUKU IV yang belum mencapai efisiensi teknis sebagai berikut:

- Bank Mandiri dapat mencapai efisiensi teknis bank dengan cara mengurangi variabel input price of labor sebesar 0,717 . Variabel price of labor merupakan biaya tenaga kerja dibagi 
jumlah tenaga kerja Hal ini memberi indikasi bahwa biaya pegawai Bank Mandiri sangat besar dan perlu di kurangi.

- Bank BRI dapat mencapai efisiensi teknis bank dengan cara mengurangi variabel input price of capital sebesar 0,622. Variabel price of capital merupakan biaya bukan bunga (NonInterest Income) dibagi aset tetap. Hal ini memberi indikasi bahwa variabel price of labor belum di manfaat dengan optimal.

- Bank NIAGA dapat mencapai efisiensi teknis bank dengan cara mengurangi dua input variabel yaitu input price of fund dan input price of capital. Pengurangan input price of fund sebesar 0,006 dan pengurangan input price of capital 0,177.

Peninjauan efisiensi teknis pada kelompok BUKU III tahun 2018 terkait penggunaan input dan output bank ditunjukkan pada tabel dibawah ini.

Tabel 7. Summary of Input Slack Kelompok Bank BUKU III 2018

\begin{tabular}{cccc}
\multicolumn{4}{c}{ Sumber: Output DEAP Versi 2.1, 2019} \\
\hline Bank & $\boldsymbol{w} \boldsymbol{1}$ & $\boldsymbol{w} \mathbf{2}$ & $\boldsymbol{w 3}$ \\
\hline Ekonomi & 0.000 & 4.181 & 0.000 \\
Bukopin & 0.376 & 0.000 & 0.000 \\
BTN & 0.024 & 0.030 & 0.000 \\
Danamon & 0.003 & 0.904 & 0.000 \\
Jabar & 0.029 & 0.685 & 0.000 \\
Jatim & 0.000 & 0.000 & 0.941 \\
Maybank & 0.019 & 1.007 & 0.000 \\
Permata & 0.016 & 1.059 & 0.000 \\
BTPN & 0.027 & 0.880 & 0.000 \\
Mayapada & 0.032 & 0.063 & 0.000 \\
Mega & 0.004 & 0.000 & 0.000 \\
OCBC & 0.010 & 0.080 & 0.000 \\
Panin & 0.000 & 0.000 & 0.000 \\
\hline
\end{tabular}

Pada Tabel 7 menunjukkan hanya Bank Panin sudah mencapai efisiensi teknis. Sementara Bank Jatim harus menurunkan biaya variabel price of labor sebesar 0,941 untuk mencapai efisiensi teknis. Sedangkan bank bank lainnya harus menurunkan dua variabel input price of fund dan price of capital.

Peninjauan efisiensi teknis pada kelompok BUKU II tahun 2018 terkait penggunaan input dan output bank ditunjukkan pada Tabel 8 di bawah ini.

Tabel 8. Summary of Input Slack Kelompok Bank BUKU II 2018 Sumber: Output DEAP Versi 2.1, 2019

\begin{tabular}{cccc} 
Bank & $\boldsymbol{w} \mathbf{w}$ & $\boldsymbol{w}$ & $\boldsymbol{w 3}$ \\
\hline Agro & 0.012 & 0.000 & 0.000 \\
MNC & 0.025 & 2.422 & 0.000 \\
Capital & 0.007 & 0.000 & 0.000 \\
Parahyangan & 0.017 & 18.435 & 0.000 \\
Bumi Arta & 0.014 & 1.307 & 0.000 \\
Ganesha & 0.016 & 5.001 & 0.000 \\
Ina Perdana & 0.026 & 13.700 & 0.000 \\
Q n B & 0.000 & 0.000 & 0.000 \\
Maspion & 0.000 & 0.000 & 0.000 \\
Sinar Mas & 0.006 & 1.234 & 0.000 \\
Victoria & 0.047 & 0.312 & 0.000 \\
China & 0.003 & 0.000 & 0.000 \\
Nobi & 0.002 & 1.794 & 0.000 \\
Woori & 0.024 & 1.269 & 0.000
\end{tabular}


Pada Tabel 8 menunjukkan bahwa kelompok bank BUKU II terdapat dua bank telah mencapai efisiensi teknis yaitu bank Q n B dan bank Maspion. Sementara bank lainnya harus menurunkan dua variabel input yaitu input price of fund dan price of capital karena kedua input variabel tersebut yang membuat bank belum mencapai efisiensi teknis. Bank Parhayangan paling tinggi mengurangi input price of capital sebesar 18,435, diikuti oleh Bank Ina Perdana sebesar 13,7. Hal ini memberi indikasi pengelolaan biaya bukan bunga (Non-Interest Income) di bagi Aset Tetap masih tinggi.

Peninjauan efisiensi teknis pada kelompok BUKU I tahun 2018 terkait penggunaan input dan output bank ditunjukkan pada Tabel 9 di bawah ini.

Tabel 9. Summary of Input Slack Kelompok Bank BUKU I 2018

\begin{tabular}{cccc}
\multicolumn{4}{c}{ Sumber: Output DEAP Versi 2.1, 2019} \\
\hline Bank & $\boldsymbol{w 1}$ & $\boldsymbol{w} \mathbf{2}$ & $\boldsymbol{w 3}$ \\
\hline Artos & 0.018 & 0.000 & 0.000 \\
Agris & 0.019 & 7.723 & 0.000 \\
India Indo & 0.014 & 0.000 & 0.000 \\
Harda & 0.031 & 0.918 & 0.000 \\
Pembangunan & 0.027 & 4.042 & 0.000 \\
Yudha & 0.042 & 2.334 & 0.000
\end{tabular}

Pada Tabel 9 menunjukkan bahwa kelompok bank BUKU I belum ada bank mencapai efisiensi teknis. Semua bank harus mengurangi biaya dua input yaitu input price of fund dan price of capital karena kedua input variabel tersebut yang membuat bank belum mencapai efisiensi teknis. Bank Agris paling tinggi mengurangi input price of capital sebesar 7,723, diikuti oleh Bank Pembangunan Banten sebesar 4,042. Hal ini memberi indikasi pengelolaan biaya bukan bunga (Non-Interest Income) di bagi Aset Tetap masih tinggi.

\section{KESIMPULAN DAN SARAN}

\section{Kesimpulan}

Penelitian ini menghitung efisiensi teknis bank di Indonesia berdasarkan kelompok Bank BUKU I-IV menggunakan metode DEAP modern dengan orientasi input variabel (input oriented). Hasil penelitian ini menunjukkan bahwa :

- Bank kelompok BUKU IV secara umum telah mencapai efisiensi teknis. Hal ini ditunjukkan pada anggota kelompok bank BUKU IV yaitu Bank BNI dan BCA merupakan bank yang bertindak efisien dengan skor efisiensi teknis $100 \%$ selama 7 tahun terakhir.

- Bank kelompok BUKU I-III belum mencapai efisiensi teknis. Kelompok bank ini harus melakukan kebijakan dengan cara mengurangi biaya dua input. Dua input yaitu input price of fund dan price of capital karena kedua input tersebut yang membuat bank belum mencapai efisiensi teknis.

\section{Saran}

Berdasarkan hasil penelitian dan kesimpulan yang diperoleh maka kebijakan yang perlu di ambil bagi kelompok bank BUKU I-III yaitu melakukan pengenduran pada Biaya bunga (Interest Expenses) dibagi dana pihak ketiga dan Biaya bukan bunga (Non-Interest Income) dibagi Aset Tetap. Selain itu, perlu dilakukan penelitian lebih lanjut terkait efisiensi teknis dengan orientasi output bank (output oriented) untuk mengkaji sejauh mana efisiensi teknis bank dalam mengelola input terhadap pencapaian output bank yaitu kredit (loans).

\section{Ucapan Terima Kasih}

Pada bagian ini saya ingin mengucapkan terima kasih pada lembaga penelitian Universitas Ciputra yang telah mendanai penelitian ini sejak awal hingga akhir. Serta ingin berterima kasih 
kepada tiga mahasiswa Prodi Manajemen Universitas Ciputra yang telah membantu pengumpulan data dan input data di karenakan banyaknya data sekunder (laporan keuangan perbankan) yang harus dikumpulkan di penelitian ini.

\section{REFERENSI}

Balcerzak, A. P. et. e. (2017). Non-parametric approach to measuring the efficiency of banking sectors in european union countries. Acta Polytechnica Hungarica, 14(7), 51-70. https://doi.org/10.12700/APH.14.7.2017.7.4

Bank Indonesia. (2018). Penguatan SSK Dalam Upaya Menjaga Momentum Pertumbuhan (2620-9241). Indonesia.

Coelli, T. J. (2005). An Introduction to Efficiency Analysis. (Second). United States: Springer Science \& Business Media.

D.hadad, M. W. S. (2003). Pendekatan Parametrik Untuk Efisiensi Perbankan Indonesia.

Grmanová, E., \& Ivanová, E. (2018). Efficiency of banks in Slovakia: Measuring by DEA models. Journal of International Studies, 11(1), 257-272. https://doi.org/10.14254/20718330.2018/11-1/20

I.Papanikolaou, M. D. D. N. (2009). Determinants of Bank Efficiency : Evidence from a semi parametric methodoloy. Economic Policy, (2116), 0-33. https://doi.org/10.1227/01.NEU.0000349921.14519.2A

Lee, Y. J. (2017). An Analysis of Korean Bank Performance Using a Double Bootstrapped DEA Analysis, XVII(2), 48-64.

Périco, A. E., Santana, N. B., \& Rebelatto, D. A. do N. (2016). Estimating the efficiency from Brazilian banks: a bootstrapped Data Envelopment Analysis (DEA). Producao, 26(3), 551-561. https://doi.org/10.1590/0103-6513.185714

Sari, P. Z., \& Saraswati, E. (2017). The Determinant of Banking Efficiency in Indonesia (DEA Approach). Journal of Accounting and Business Education, 1(2), 208. https://doi.org/10.26675/jabe.v1i2.8489

Sharma, A. K., Sharma, D., \& Barua, M. K. (2012). Efficiency and Productivity of Indian Banks : An Application of Data Envelopment Analysis and Tobit Regression, (January 2016), 81-90. https://doi.org/10.13140/RG.2.1.2827.6886

Stewart, C., Matousek, R., \& Nguyen, T. N. (2016). Efficiency in the Vietnamese banking system: A DEA double bootstrap approach. Research in International Business and Finance, 36, 96-111. https://doi.org/10.1016/j.ribaf.2015.09.006

Tlig, H. (2013). A Fuzzy Data Envelopment Analysis model to evaluate the Tunisian banks efficiency. International Journal of Scientific \& Engineering Research, 4(9), 1924-1929. Retrieved from http://www.ijser.org

https://ojk.go.id/id/data-dan-statistik/laporan-tahunan/Pages/Laporan-Tahunan-OJK-2018.aspx 